UDC 81'25:81'373=111

DOI https://doi.org/10.32838/2710-4656/2021.1-2/51

Yukhymets S. Yu.

Odesa National Maritime University

\title{
ETHNO-PSYCHOLINGUISTIC STEREOPTYPES IN TRANSLATIONAL ASPECT
}

The article is dedicated to the problem of the interdisciplinary character which is urgent for both ethno- and socio-psycholinguistics. In the focus of the research there are the peculiarities of the language stereotypes in the representatives of different nations and cultures, the specificity of the communicative conflict is described. On the basis of the language behavior peculiarities analysis there has been elaborated the typology of ethno-psycholinguistic stereotypes. It has been concluded that the problem of the manifestation of ethno-psychological stereotypes in the speech of Englishmen is inseparable from the issue of their adequate rendering by means of typologically distant languages on different linguistic levels and via various language devices.

There have been outlined distinguished features of English ethno-psycholinguistic stereotypes and possible challenges of their rendering in translation. The classification of the communicative competence levels, based upon the language personality's ability to cooperate in interpersonal communication is also adduced in the article. Different communicative situations have been analyzed and the common conclusions have been drawn. All the results have been statistically proved. The translation strategies, tactics and operations at work have been thoroughly studied. The findings of the research may be useful for the solutions of the urgent problems of intercultural communication and may also be employed as a powerful means of translation optimization with regards to the crosscultural discrepancies. The topicality and novelty of the research make it up-to-date and promising both in translation studies and linguistics. The perspective is seen in investigating ethno-psychological stereotypes revealed in American English.

Key words: ethno-, sociopsycholinguistics, communicative conflict, ethnopsychological stereotypes, communicative competence.

Problem statement. The issue of ethno-psycholinguistic stereotypes research is interdisciplinary due to its origin on the basis of psycholinguistics, sociolinguistics and ethnolinguistics. The close interaction of psycholinguistics with sociolinguistics and ethnolinguistics has preconditioned the discursive breakthrough in Arts and Humanities resulting in the shift from the text-centered to the person-centered paradigm.

Analysis of recent research and publications. Such notions as "linguistic personality", "speech portrait", "social stereotype" and "ethno-psycholinguistic stereotype" have become key concepts in Philology. While socio-psycholinguistics is focused mainly on the reflection of socially relevant processes and phenomena in the linguistic personality [3], ethnolinguistics investigates chiefly stereotypes of the linguistic behavior of different nations.

The foundation of this approach was laid by M. M. Bakhtin, who first introduced the term "the speaking personality" in 1920s [2]. Such primary understanding of the linguistic personality was grounded by the socially determined origin of the personality itself. The actualization of the inner sensations and emotions was seen in the socially conditioned nature of the communicative situation with all its constituents and the circumstances.

The domain of the everyday interpersonal communication of the liguistic personalities was further investigated by Yu. M. Karaulov, who could distinguish a linguistic personality hidden behind any text product [7]. In spite of the great number of studies in the field of social and ethno-psycholinguistics the issue of formulating the linguistic personality's typology has not been fully elaborated yet.

The object of the research is ethno-psycholinguistic stereotypes, the subject - language means of realizing peculiarities of ethno-psycholinguistic stereotypes in English and the dominantstrategies, tacticsand operations of their rendering in Ukrainian translation.

The urgency of the research is predetermined by the insufficient investigation of the issue of linguistic personalities typology on the whole and the ethnopsycholinguisticstereotypesclassificationinparticular, the necessity of the complex analysis of the ethnopsycholinguistic stereotypes both on the language and speech levels and the peculiarities of rendering in translation. 
Setting a task. The objective of the research lies in determining the peculiarities of the ethnopsycholinguistic stereotypes of Englishmen's behavior in the aspect of their rendering in Ukrainian translation and selection of the proper strategies, tactics and operations.

To achieve the objective the following steps should be taken: to study the theoretical resources on the chosen topicality; to define the following concepts as "social stereotype", "linguistic personality", "language portrait"», "ethno-psycholinguistic stereotypes"; to analyze linguistic means of realizing the peculiarities of ethno-psycholinguistic stereotypes in English; to study strategies, tactics and operations of rendering phenomena under research in Ukrainian.

In accordance with the object, subject, objective and tasks the following research methods have been employed: the method of theoretical generalization to describe the theoretical resources; the comparative method to contrast source texts in English and translation texts in Ukrainian, the analytical method to characterize the material of investigation. The investigation was carried out on the basis of the book by Kate Fox "Watching the English. The Hidden Rules of English Behavior" and its authorized translation into Ukrainian «Спостерігаючи за англійцями» [10; 11].

Presentation of the main material. The whole scope of the material under investigation was selected to illustrate the peculiarities of the behavior of different ethno-psycholinguistic stereotypes of linguistic personalities in the communicative situation. The distinctive features were revealed through both personal individual peculiarities and typologically common ethnic and psycholinguistic stereotypes. Thus there were outlined three types of linguistic behavior: invective linguistic behavior, polite and rationally heuristic linguistic behavior.

Invective linguistic behavior is distinguished by the communicative manifestations of the individual's emotional and biological responses. Polite linguistic behavior is revealed by the communicant's inclination to the etiquette of the forms of social interaction. Rationally heuristic linguistic behavior is based upon the reserved manner, prevalence of sense over sensations $[4 ; 5]$.

The communicative conflict is a powerful vehicle of emotional release; stress relief is a key factor resulting in manifestation of the speaker's linguistic behavior type and ethnic psychological stereotypes illustration. Psychological purification by language means is often referred to as verbal catharsis $[5 ; 7 ; 8]$.

Various personalities differ in manifesting their verbal catharsis [3]. For the Russian native speakers the main means is employment of obscenities; for
Ukrainians - paremias, folk songs, ritual songs, ditties; for Englishmen - sarcastic utterances, funny stories, jokes and puns, limericks.

According to K. Fox's observation, "the nucleus" of "Englishness" is inclination to underestimate everything, wide distribution of litotes and meiosis, distinctive «upper lip smile», tendency to irony. Still another distinctive trait is speech euphemization, willing to disguise negative emotions [11].

According to $\mathrm{K}$. Fox's classification there are distinguished communicatively distinctive codes of speech and socially or communally differentiated or identified class linguistic codes [11].

No less than linguistic codes speech behavior rules in certain communicative situations serve as indicators of English linguistic personality (casual conversation at home, conversation in public transport, in a pub, in a car, in the line. Moreover, there may be also distinguished rules of humor, rules of confusion, rules of modesty, rules of complaint, rules of ambivalence and class behavior.

Ethnic-psycholinguistic stereotypes of linguistic behavior may be analyzed only for the nations with distinct and peculiar national temperament and cultural individuality [11, p. 49]. That's why K. Fox's book was dedicated to the English and not to the British. The British nation is rather a complex conglomerate than a nation in its traditional understanding. Nevertheless, the stereotypes of the behavior of the English are also true for the Welsh, the Irish and the Scottish.

Among the most widespread English ethnicpsychological stereotypes there are such as "restraint", "politeness", "talks about weather", "pretense", "privacy", "anti-intellectuality", "queue rules", "compromise", "fair game", "humor", "mannerism", "eccentricity". This is a multi-layered pie, each stratum of which should be researched in detail. The objective of the research was not only to outline the basic means of manifesting "Englishness", but also to define strategies, tactics and operations of their rendering in Ukrainian translation [11, p. 80].

The analysis of the ways of ethnic-psychological stereotypes realization has witnessed the complex character of diverse multilevel language means employment, in particular phonological, lexical, morphological and syntactical.

The phonological features of English speech are the most prominent, vivid and most easily distinguished means of realizing ethnic-psychological stereotypes. In particular, this is the employment of the High Pre-Head in combination with the Scandent Head and the nuclear Rising-Falling tone for rendering such emotions as astonishment and sarcasm; the employment 
of the Falling Sliding Head in combination with the High Falling nuclear tone to express aggression or antipathy.

The lexical means of realizing peculiarities of ethnic-psychological stereotypes are a powerful means of rendering the disguised sensations, overcoming the tension, expressing irony etc. Alongside with the wide distribution of evaluative lexis euphemisms are relatively numerous ("go to the bathroom", "go to the wind", "pass away", "join the silent majority", "go tipsy", "a bit under the weather" [11, p. 80]. Also typical there is wide distribution of stylistic devices, based upon the contrast or synergy of incompatible concepts, in particular devices or antithesis, oxymoron, zeugma and paradox.

It should be emphasized that communicative conflict is associated with emotional release and stress relief. This effect is similar to catharsis or psychological purification. Different linguistic personalities tend to various manifestations of verbal catharsis. Thus, invective linguistic personalities explode with direct verbal aggression, rational and heuristic personalities are more inclined to irony.

Linguistic behavior of a personality in a conflict situation reveals ethno-psychological stereotypes. Everyday conflicts as a rule arise due to the dissatisfaction of one of the communicants with the conduct of the other or others. This dissatisfaction may sometimes result from an implicit conflict, distinguished due to the diversity of the communicants' speech strategies. Irony is a very powerful means of English criticism and pessimism. Irony may be based both upon the contrast of the employed lexical and phraseological means and on the contradiction of the vocabulary and intonation patterns at work. To illustrate this tendency the following examples may be adduced.

Example I.

A: Look! It's raining!

B: Raining? It's raining cats and dogs, actually! It's 'pouring with rain, I must say!

Example II.

A: Hello, Tony. Did you go for your interview yesterday?

B: Hi, Lisa. Yes. I did.

A: How did it go?

B: All right, I think.

A: All 'right? You don't sound very 'sure [1, p. 22].

The problem of the manifestation of ethnopsychological stereotypes in the speech of Englishmen is inseparable from the issue of their adequate rendering by means of typologically distant languages on different linguistic levels and via various language devices.

The most relevant in representing ethno-psychological stereotypes in the speech of Englishmen by means of the Ukrainian language while translating is given to vocabulary. The linguistic representatives of English litotes and sarcasm, key means of meiosis realization aimed at deliberate understatement of importance, relevance of certain features or qualities ("quite", "relatively", "seemingly") precondition challenges in English-Ukrainian translation due to the difficulty in selecting an appropriate equivocabular equivalent or analogue. Therefore, complex lexico-grammatical transformations of antonymous translation or contextual replacement are most widely employed in this case. Such observation may be illustrated by the following examples.

English: "As for me, this pudding seems quite eatable".

Ukrainian translation: «Як на мене, це тістечко здається таким собі їстівним».

As itmay be seen, in such case contextual replacement was applied as a translation operation at work.

There is also possible another variant of translation, by means of the transformation of semantic development in which reason is replaced by effect in the translated text.

English: "As for me, this pudding seems quite eatable".

Ukrainian translation: «Як на мене, це тістечко можна їсти».

On the basis of the findings of the analysis of the ethno-psychological stereotypes representation means distribution the table and diagram, illustrating translation transformations employment frequency have been completed. Contextual replacement has proved to be most recurrent, with antonymous translation and semantic development being a bit less frequent.

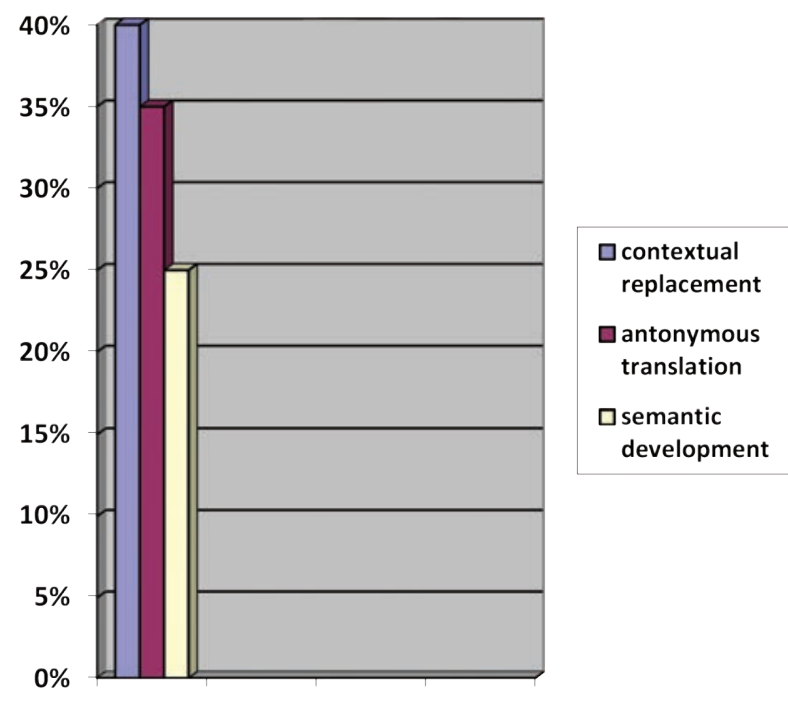

Fig. 1. Translation transformations employment frequency in rendering ethno-psychological stereotypes representation means in translation 
Table 1

Translation transformations employment frequency in rendering ethno-psychological stereotypes representation means in translation

\begin{tabular}{|c|c|c|}
\hline $\begin{array}{c}\text { Translation } \\
\text { transformation }\end{array}$ & $\begin{array}{c}\text { Frequency, } \\
\%\end{array}$ & Examples \\
\hline $\begin{array}{c}\text { Contextual } \\
\text { replacement }\end{array}$ & 45 & $\begin{array}{c}\text { "upper-lip } \\
\text { smile"- «англійська } \\
\text { посмішка» }\end{array}$ \\
\hline $\begin{array}{c}\text { Antonymous } \\
\text { translation }\end{array}$ & 35 & $\begin{array}{c}\text { "You can't be } \\
\text { serious!" - «Ви, } \\
\text { напевно, шуткуєте!» }\end{array}$ \\
\hline $\begin{array}{c}\text { Semantic } \\
\text { development }\end{array}$ & 25 & $\begin{array}{c}\text { "Рardon!"- } \\
\text { «Перепрошую. Що } \\
\text { Ви сказали?» }\end{array}$ \\
\hline
\end{tabular}

The main translation tactics have proved to be the tactic of national-cultural background preservation, the tactic oflinguistic-cultural adaptation and the tactic of correct information presentation.

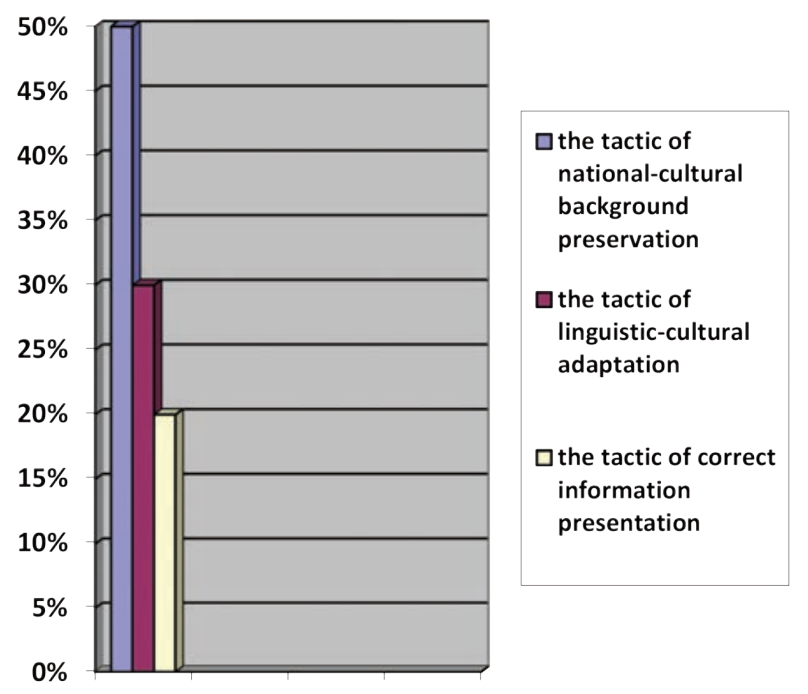

Fig. 2. Translation tactics employment frequency in rendering ethno-psychological stereotypes representation means in translation

It's worth dwelling upon the distinctive features of various ethno-psychological personality types: conflict type, centric type and cooperative type.

Conflict type is characterized by explicit negative illocution addressed to co-communicants, manifesting hostility. Centric type is distinguished by the egocentricity and deliberate neglect to other communicants. Active egocentrics do not need recipients; they don't give anyone any chance to interrupt their discourse. Communicative acts of such kind are bound to be a failure.

Cooperativetype is determinedbyexplicitaloofness and expressed superiority in communication. For the fear of arising conflict one of the communicants chooses conformist behavior. He or she willingly express their loyalty and full affirmation of the ideas shared by means of echoing, appraisal phrases and gestures. Sometimes this kind of communication even resembles some imitation or copying.

Table 2

Translation tactics employment frequency in rendering ethno-psychological stereotypes representation means in translation

\begin{tabular}{|c|c|c|}
\hline $\begin{array}{l}\text { Translation } \\
\text { tactic }\end{array}$ & $\begin{array}{c}\text { Frequency, } \\
\%\end{array}$ & Examples \\
\hline $\begin{array}{c}\text { The tactic } \\
\text { of national-cultural } \\
\text { background } \\
\text { preservation }\end{array}$ & 50 & $\begin{array}{c}\text { "The proof } \\
\text { of the pudding is in } \\
\text { the eating" - «Hе } \\
\text { оцінюй пудинг, } \\
\text { доки його не } \\
\text { скуштуєш» }\end{array}$ \\
\hline $\begin{array}{l}\text { The tactic } \\
\text { of linguistic- } \\
\text { cultural adaptation }\end{array}$ & 30 & $\begin{array}{l}\text { "He who laughs } \\
\text { at crooked } \\
\text { men should } \\
\text { need walk very } \\
\text { straight” - «Який } \\
\text { «добрий день», } \\
\text { такий і «будь } \\
\text { здоров»»» } \\
\end{array}$ \\
\hline $\begin{array}{l}\text { The tactic of correct } \\
\text { information } \\
\text { presentation }\end{array}$ & 20 & $\begin{array}{l}\text { "There is no such } \\
\text { thing as a free } \\
\text { lunch"-«Безкоштовних } \\
\text { сніданків не буває» }\end{array}$ \\
\hline
\end{tabular}

The highest level of language personality self-realization in communication is cooperativeactualized behavior type, corresponding to the highest level of communicative competence. Linguistic personality is known by self-respect and ability to openly express ideas. One of the key communicative parameters differentiating different types of linguistic personalities is the so-called "idle talk".

The social-psychological background contributes to the associative behavior of the communicants. The game rules are to idly discuss some matters of little importance instead of being involved into a debate or business conversation. This is connected with the communicants' global intentions and general implicit modality. The objective of the conversation is not to obtain some particular information but rather to attain psychological comfort.

In such communicative situation different types oflinguistic personalities behave differently. Conflictive aggressor employs such tactics as invective tactics, blaming and bullying tactics; conflictive manipulator realizes communicative intentions in orders, requests, commitments, instructions, recommendations; active egocentric imposes communicative tactics, ignores 
communicants' ideas, suggestions and expectations; cooperative conformist agrees with everything, expresses support and approval.

Conclusions and offers. According to the results of strategies, tactics and operations of rendering in Ukrainian translation linguistic means of manifesting ethno-psychological stereotypes of the Englishmen, the key strategy has proved to be the strategy of communicative and relevant translation. As for the tactics, the most recurrent tactics are the tactic of national-cul- tural background preservation, the tactic of linguistic-cultural adaptation and the tactic of correct information presentation. As far as translation operations are concerned, the prevailing translation transformations have proved to be contextual replacement, antonymous translation and semantic development.

The perspective is seen in investigating ethnopsychological stereotypes revealed in American English and in distinguishing the most appropriate techniques of their rendering in Ukrainian translation.

\section{References:}

1. Bradford B. Intonation in Context. Cambridge University Press, 1988. 52 p.

2. Бахтин М. М. Фрейдизм. Формальный метод в литературоведении. Марксизм и философия языка. Статьи. Москва : Лабиринт, 2000. 424 с.

3. Берн Э. Игры, в которые играют люди. Психология человеческих взаимоотношений. Люди, которые играют в игры. Психология человеческой судьбы. Москва ; Санкт-Петербург : Университетская книга, 1997. 399 c.

4. Flick U. Social representations. Rethinking Psychology. London, 1995. P. 70-96.

5. Горелов И. М., Седов К. Ф. Основы психолингвистики. Москва : Лабиринт, 2001. С. 161-176.

6. Harre R. Discursive psychology. Rethinking Psychology. London, 1995. P. 143-159.

7. Дементьев В. В. Непрямая коммуникация и ее жанры. Саратов : изд-во Саратовского университета, 2000. $248 \mathrm{c}$

8. Дементьев В. В., Седов К. Ф. Теория речевых жанров: социопрагматический аспект. Stylistyka 8. Opole. 1999. S. 53-87.

9. Седов К. Ф. Типы языковых личностей и стратегии речевого поведения (о риторике бытового конфликта). Вопросы стилистики. Язык и человек. Саратов : изд-во Саратовского университета, 1996. Вып. 26. С. 8-14.

10. Фокс К. Спостерігаючи за англійцями / пер. $з$ англ. М. Госовської. Львів : Видавництво Старого Лева, 2018. 608 с.

11. Fox Kate Watching the English. The Hidden Rules of English Behavior. London : Hodder \& Stoughton, 2014. $608 \mathrm{p}$.

\section{ЮХИмеЦь С. Ю. ЕТНОПСИХОЛІНГВІСТИЧНІ СТЕРЕОТИПИ В ПЕРЕКЛАДІ}

У статті визначено відмінні особливості англійських етнопсихолінгвістичних стереотипів та можливі труднощі їх відновлення у перекладі. Наведено класифікацію рівнів комунікативної компетениії, підтрунтям для якої стала здатність мовної особистості до кооперачії у міжсособистісному спілкуванні, описано й досліджено провідні стратегії, тактики й операчії відтворення у перекладі українською мовою етнопсихолінгвістичних стереотипів англійської мови. Проаналізовано різні комунікативні ситуації та сформульовано загальні висновки. Усі результати піддано статистичній перевіриі. Детально досліджено задіяні стратегії, тактики та операџії перекладу. Результати дослідження можуть стати у нагоді під час вирішення нагальних проблем міжкультурної комунікачії, теорії та практики перекладу та слугуватимуть потужним засобом оптимізаиії якості перекладу з урахуванням крос-культурних відмінностей. Тематика розвідки має перспективу подальшого розроблення і вдосконалення на часі з напрямом сучасних мовознавчих і перекладознавчих студій. Перспектива вбачається у дослідженні етнопсихолінгвістичних стереотипів у американському варіанті англійської мови.

Ключові слова: етнопсихолінгвістика, сочіопсихолінгвістика, комунікативний конфлікт, етнопсихолінгвістичні стереотипи, комунікативна компетенщія, стратегї̈, тактики й операщії перекладу. 